Meta

Journal des traducteurs

Translators' Journal

\title{
A Promising Research Ground: Translation Historiography in Brazil
}

\section{Lia Wyler}

Volume 50, numéro 3, août 2005

Le prisme de l'histoire

The History Lens

URI : https://id.erudit.org/iderudit/011600ar

DOI : https://doi.org/10.7202/011600ar

Aller au sommaire du numéro

Éditeur(s)

Les Presses de l'Université de Montréal

ISSN

0026-0452 (imprimé)

1492-1421 (numérique)

Découvrir la revue

Citer cet article

Wyler, L. (2005). A Promising Research Ground: Translation Historiography in Brazil. Meta, 50(3), 851-857. https://doi.org/10.7202/011600ar
Résumé de l'article

Au Brésil, les études d'histoire de la traduction ont débuté à la fin des années 1980 et leur développement a été tel qu’elles formaient déjà, en 1998, un champ autonome dans les congrès de traduction. Les théories de Lefevere, de Toury et de Holmes sont aujourd'hui appliquées à de grands corpus de traductions produites entre les années 1940 et 1970, pour chercher à dévoiler les pratiques éditoriales ayant influencé la traduction d'oeuvres de fiction et la formation d'un public de lecteurs pour ce genre. Les nouvelles tendances dans ce domaine incluent le recours à un plus grand nombre de ressources humaines pour mener à bien des projets d'envergure, et un intérêt sur la manière dont les contraintes du marché influent sur le travail du traducteur.
Ce document est protégé par la loi sur le droit d'auteur. L'utilisation des services d’Érudit (y compris la reproduction) est assujettie à sa politique d'utilisation que vous pouvez consulter en ligne.

https://apropos.erudit.org/fr/usagers/politique-dutilisation/ 


\title{
A Promising Research Ground: Translation Historiography in Brazil
}

\author{
LIA WYLER \\ Researcher in Translation History, Rio de Janeiro, Brazil \\ lia.wyler@terra.com.br
}

\begin{abstract}
RÉSUMÉ
Au Brésil, les études d'histoire de la traduction ont débuté à la fin des années 1980 et leur développement a été tel qu'elles formaient déjà, en 1998, un champ autonome dans les congrès de traduction. Les théories de Lefevere, de Toury et de Holmes sont aujourd'hui appliquées à de grands corpus de traductions produites entre les années 1940 et 1970, pour chercher à dévoiler les pratiques éditoriales ayant influencé la traduction d'œuvres de fiction et la formation d'un public de lecteurs pour ce genre. Les nouvelles tendances dans ce domaine incluent le recours à un plus grand nombre de ressources humaines pour mener à bien des projets d'envergure, et un intérêt sur la manière dont les contraintes du marché influent sur le travail du traducteur.
\end{abstract}

\begin{abstract}
In Brazil, studies in Translation History began in the late eighties and expanded to the extent that by 1998 they had become an area per se in translation fori. The theories by Lefevere, Toury and Holmes are being applied to large corpuses of translations produced from the forties to the seventies in an effort to disclose publishing practices affecting the translation of fiction and the formation of a readership for this genre. New trends in the field include the pooling of human resources to deal with larger projects and an interest in how market demands affect the work of translators.
\end{abstract}

\section{MOTS-CLÉS/KEYWORDS}

Brazil, translation history, translation of fiction, publishing

Today, Translation Historiography in Brazil can be viewed as a wide, promising research ground. This was not so in the early 1990's when the surface of Descriptive Studies had hardly been scratched and researchers could try but not really succeed in evaluating their meager findings in the light of imported theories, given the marked differences between conditions surrounding the translation of texts in other countries and in Brazil. On the other hand, the idea of a historiography of translation was so new that they had not yet had time to construct theoretical frameworks of their own.

There were no post-graduate courses in translation in the country and the 24 theses and dissertations on translation presented up to 1989 came from the areas of Comparative Literature (with particular emphasis on poetry), Linguistics, Literary Theory, Philosophy, Semiotics and Psychoanalysis.

In the last sixteen years, however, there has been an upsurge of post-graduate courses lato sensu in major and minor universities. Last year (2004), topping off other achievements such as the regular publication of a translation journal, Cadernos de Tradução, the Federal University of Santa Catarina succeeded in licensing the very first post-graduation course stricto sensu in Translation Studies. 
Many initiatives have contributed to these advances, particularly the Translation Forums organized more regularly as from 1985, where academics and professional translators began to meet every two or three years to discuss their theory and practice.

In Milton (1993) the author gives us a brief but clear picture of Translation Studies in the years surrounding that Forum. Until then translators were familiar with re-creation and dominance of form over content, theories that were developed by poet-translators Augusto de Campos and Haroldo de Campos, influenced by Walter Benjamin, Roman Jakobson and Ezra Pound, though they never committed themselves or their poetry politically. They were also acquainted with the argument by poet-translator José Paulo Paes that a poet's idiolect is nothing but the power to name things given to man by God, and with his counter argument that, in naming things, the poet reinforced the sociolect of the time and place he lived in and the society he wrote for. So there was a general awareness of the power of the "sujet traduisant" but this power had not been explicitly linked to the times and conditions that surrounded him and his text - that is, to their historicity.

A few years before, Rosemary Arrojo had stressed the importance of social context in the choices made by translators. Arrojo (1986) introduced the post-structuralist theories of Roland Barthes, Jacques Derrida and Stanley Fish, and discussed the ideas of interpretive community, original text versus palimpsest-text. The latter would be a text erased by each successive community, reinterpreted according to its perceptions and accepted by that particular community as the "same" text. In the years that followed, her theorization became the starting point and foundation for a large number of essays, articles, theses and dissertations in major academic institutions where she taught or was invited to speak.

Not as well publicized in Brazil as Arrojo's books and articles, a doctoral dissertation by Vieira (1992), discussed the concept of cannibalism, which was in her view a distinctive trace of Brazilian translations - a consistent refusal to privilege the original text over its translation. She considered that Derrida's and Benjamin's ideas lacked the theoretical coherence that could be found in Peirce and summed up by finding André Lefevere's refraction of texts as refractions of a culture not only compatible with Peirce but better able to study the formation of images and cultural canons through translations. Vieira's ideas were taken up by Susan Bassnett, Edwin Gentzler and others academics abroad and had important repercussions in the United Kingdom and the United States.

Now once one starts thinking about cannibalism and refractions, next he/she will be thinking about dependency, the forms it assumed throughout a country's literary history and inevitably of one of the agents of these manifestations: the translator. So, in 1983, when Paes was asked by a newspaper in São Paulo to write an article for a special issue on translation he took the opportunity and wrote about literary translations and translators. Not how they should feel or how they should approach their task, but who they actually were and what books they translated. Press articles, however, are short-lived and his was forgotten until some seven years later when it came out in book form. Paes (1990), was a collection of short essays on literary translation issues such as metaphor and memory, the poetry of Manuel Bandeira, Milan Kundera's views on translation, translation criticism and history. His first attempt to put together a history of literary translation has never ceased to impress those who read it. Besides having the quality of absolute novelty it also included a comprehensive 
bibliography that has given direction and purpose to the work of many researchers who were stimulated by the challenge of tackling the "cyclopean task" of writing a more complete account.

Around six years were necessary to gather enough data about the first four centuries of European invasions and settlements, a period in which we are informed that interpreters abounded in Brazil. But either little was written about them or the records are lost or carefully locked away in Portugal's colonial archives. Even so, it was possible to glean some information from passing comments in old chronicles and voyage diaries and legal documents written from the16th to the 19th centuries and republished in "Brasilianas" during the 1940s. The registers referring to the 19th century, however, are more numerous and detailed as they have been the object of study of scholars. The results of my research covering the years 1500 to 1900 were presented as a MA thesis in 1995, and with the first seventy years of the 20th century added, were published as a book in 2003. Parts of this research can also be found in "Brazilian Tradition."

The thesis, an overview of what could later become a full-sized history, attracted the attention of researchers working under John Milton's supervision on translation from a historiographical point of view at the University of São Paulo. He had been very active in organizing events where Brazilian researchers could have a first hand contact with European and American researchers who were developing theories on translation from various points of view but especially from a historical approach.

At this point it should be noted that the frequent presence of foreign descriptivists in lectures and bibliographies from the early nineties was probably stimulated by the opening of Cetra summer courses in Leuven, in 1989. These courses were attended by a number of Brazilian researchers from different universities and the theories taught there have since informed most of our production in the area of descriptive studies and historiography.

Soon this interest in historiography was no longer restricted to the University of São Paulo. In the 1996 Forum in Fortaleza, Ceará, the plenaries of Michel Ballard, Edwin Gentzler and Judith Woodsworth attracted large audiences showing that there was enough public to justify the opening of a separate area of activities for historiography and descriptive studies in future fori. So for next one in 1998, the well-known theoreticians Lieven D'hulst and Anthony Pym were invited to discuss their methods in historiography.

Three Brazilian specialists on literature and theatre, Gilberto Passos, Pina Coco and Tania Brandão, were also invited to speak at the 1998 Forum about the role of translation in their respective areas, and to try to fill in the many gaps observed in Brazilian cultural production throughout colonial times. For them, this change of point of view was quite a new experience, for it is well known how reluctant academics from ex-colonies are to acknowledge the overpowering role of translation in the cultural production of their countries. Their focal point necessarily being the study of a national literature, it can only be expected that they should discard translations as manifestations of "Other" cultures holding no interest for their purpose. Actually there have been some studies that do mention translations but as evidence to corroborate their views on French literature and its influence in 19th century Brazil. Such is the case of Meyer (1996), a lengthy work initially intended to search for the Anglo-French origins of the Brazilian romance. Many such studies also reveal that 
this was by no means a one way inflow, a point that has been taken up by translation researchers Aguiar from the UFG (Universidade Federal de Goiás) and Torres from UFSC (Universidade Federal de Santa Catarina) when studying French translations of Brazilian authors for their PhD's dissertations. Nor has it involved France only according to Barbosa who made a survey of works translated in the United Kingdom and the United States correlating them to Brazilian literary historical periods.

Conferences, round tables and papers presented at the 1998 Forum not only showed new research possibilities but evidenced as well that a vast ground remained untilled, work-hands were few and worked far apart, and often duplicated work already done or underway. It also stressed that the fact that translation was not a discipline per se hampered nationwide initiatives such as forming a data bank with all our findings or concentrating on pure translation studies or even using Internet to speed up the exchange of information. Gathering data for this article, for instance, was something that demanded sending personal messages to the researchers and waiting a long time for their replies. A general announcement made on the information list coordinated from the University of São Paulo, Tradinfo, received only a couple of replies.

But in spite of these setbacks, many initiatives begun in1998 have borne good fruit. The papers on historiography presented then were collected and edited by John Milton in a special issue of Crop. Though its preparation began as soon as the Forum was over, it ended up being published in 2001. It had a preface by Lieven D'hulst on "Why and how to Write Translation Histories?" and included eight articles from different theoretical approaches that ranged from overviews of a few centuries to detailed descriptions of certain translators and their work on a given author, from translations for the Book Club and for collections in Brazil and Argentina to a discussion of Tupi names surviving in contemporary Brazil. But primarily it showed, according to its editor, the "growing popularity of the area of historical translation studies in Brazil," and gave visibility to the work of Eduardo de Almeida Navarro, Tania Brandão, Maria Cristina Batalha, Irene Hirsh, Adriana Pagano, John Milton and my own.

The idea of publishing in one volume the work of academics from different universities and even different countries on a single theme was taken up by Marcia Martins (1999) with articles by Australian Anthony Pym, Belgian Lieven D'hulst, Frenchman Michel Ballard, Egyptian Mona Baker, Briton John Milton working in Brazil and Brazilians Lia Wyler, Marcia Martins and Aguiar.

Throughout the nineties, the interest in descriptive studies has continued to grow and as in other countries they have expanded to cover literary and non-literary translations, oral interpreting, dubbing and subtitling as well as the development of theoretical frameworks, case studies, translator training and translation assessment. An initial sampling of this work can be seen on a CD-Rom organized by Pagano for the 2000 Forum, containing 95 articles, thesis and dissertation abstracts published up to that date.

The concepts and methods proposed by the polysystems theory have been used by Hirsch (2002) when describing Brazilian translations of 19th century American writers published in the 20th century for her $\mathrm{PhD}$. She concluded that these translations contributed to the progressive Americanization of reading habits in Brazil as from the early twenties, helping to form a book market dependent on translations. 
The polysystems theory has also been successfully adapted to describe audiovisual translations as shown by the pioneering research of Santiago at the University of Ceará. The main points of her PhD can be found in a recent article in Meta (2004). Other research developed by herself and colleagues on closed subtitling was published in 2003, and 2004.

Another interesting development is the high number of undergraduate dissertations presented at the conclusion of Diploma or graduation courses on Brazilian and foreign literatures and language teaching. In an article soon to be published, Maria Clara Castellões from UFMG (Universidade Federal de Minas Gerais) mentions six dissertations from one class in which students develop the concepts of rewriting and manipulation, patronage, domestication and foreignization to discuss North American texts translated in Brazil. In half of them students examine the translations of translator, writer, publisher and politician Monteiro Lobato, translator and writer Raquel de Queiroz and again Editora Globo; one examines the reception of George Orwell's Animal Farm in Brazil.

The same phenomenon has been observed at Pontificia Universidade Católica de Rio (PUC-Rio) and other universities in the country, making it very difficult for a single researcher to keep up with what goes on or where, except in the case of students that continue their research for MA.'s and PhD.'s. In general, these dissertations and theses are informed by descriptive theories, especially by Holmes, Toury and Lefevere, sharing also Venuti's assumptions on the key role played by translation in the formation of cultural identities and domestic canons of foreign literature. Explicit and implicit translators interventions in texts and the ceaseless movement between the points of view of the foreigner and that of the domestic are the focus of research carried out at UNESP (Universidade Estadual Paulista), as exemplified by Cristina Carneiro Rodrigues's project on Richard Burton's account of his travels through Brazil and its Brazilian translations.

The expansion of descriptive translation studies (DTS) has turned Historiography into just one more possibility in this vast field and not a very attractive one I would say, as students of Language and Literature are not as keen on History as students of Social Sciences. From this area came two excellent projects, organized by Jerusa Pires Ferreira who so far has published seven long interviews by editors who, in her opinion, have played an important role Brazilian publishing. Since a large number of publishers rely heavily on translation until they find their own niche in the market, these interviews are a useful source for historians of translation. The other project, concluded by Sonia Amorim (1991), recounts in detail the success story of Editora Globo during the forties and fifties. Its photographs, book covers and list of titles and even anecdotes have been invaluable for those studying the period covered by her dissertation.

Probing into less visible publishers, John Milton (2002) gives us a comprehensive study, in which he tries to recover the impact of Clube do Livro editions on the Brazilian readership and their reading habits during the fifties and sixties. Drawing from the possibilities offered by André Lefevere's concept of refraction he examines both the politically correct and pseudotranslations as well as the use of teamwork and standardization to translate and edit books.

More recently there has been a tendency to pool human resources: groups at UFSC (Universidade Federal de Santa Catarina) and UFMG are coordinating efforts 
to map out all translated literature in the twentieth century using as their main source Unesco's Index Translatiorum. From PUC-Rio, Martins (2004) has organized papers on translations of Shakespeare bringing together academics who work in Literature and Translation Departments in universities located in various states of Brazil such as Minas Gerais, Rio Grande do Sul, Rio de Janeiro, São Paulo and Santa Catarina.

In view of the amount of translation done in Brazil, academics have also begun to show concern about the existing split between theory and practice and have tried to get the translator's cooperation to solve the dilemma. In 2003, Ivone Benedetti (Universidade de São Paulo - USP) and Adail Sobral (Pontificia Universidade Católica de São Paulo - PUC-SP) coordinated a book intended to paint a more accurate picture of translation in Brazil. Twenty-two experienced professional translators were asked to describe their work, answering a set of ten complex questions that included their relations with clients, publishers and society, their target readers, their training, globalization, machine translation and translation memories, errors, payment and translation reviews in the media. The results were extremely interesting as they revealed the enormous variation in the way translators viewed their profession as well as the expectations of the market which condition their practice.

The same interest has been shown by Marileide Esqueda (Universidade de Campinas - UNICAMP) who has already covered a lot of ground recovering and analyzing texts on theory and practice written from the fifties to the eighties by Paulo Rónai, a coordinator of translated collections and encyclopedias a well as the founder of the translators' Union back in the seventies. In both her M.A. and Ph.D. projects, Esqueda searched for a link between translators' current practice, Rónai's theories and his attempt to regulate the translator's profession in 1977.

Quoting Anthony Pym, the history of translation requires strong empirical spadework if it is to provide satisfying fruits. Apparently we are on the right path although many years will be needed just to map and analyze books translated in Brazil in the last sixty-five years, not to mention newspapers and theater plays published in the 19th and 20th centuries. But it will also be essential to get the cooperation of Portuguese scholars to map out and analyze 440 years of translated works exported by Portugal to Brazil.

\section{REFERENCES}

Aguiar, O. B. de (1998): "Par la pantoufloche de la pantouflochade!: a questão das variações lingüísticas em uma tradução de Os miseráveis," Tradterm 5-2, p. 97-119.

Aguiar, O. B. de (1999): "Tradução e literatura: os folhetins traduzidos e a introdução da obra de ficção em prosa." In Martins, M. A. P. Tradução e multidisciplinaridade, Rio de Janeiro, Lucerna, p. 136-152.

Amorim, S. (1991): De Agatha Christie a Marcel Proust (1930-1950), M.A. Thesis, São Paulo, ECA-USP.

Arrojo, R. (1986): Oficina de tradução, São Paulo, Ática.

BAKer, M. (ed.) (1998): “Brazilian Tradition,” Routledge Encyclopedia of Translation Studies.

Barbosa, H. (1994): The virtual image: Brazilian literature in English translations, Ph.D. Dissertation, University of Warwick, England.

Benedetti, I. And A. Sobral (eds.) (2003): Conversas com tradutores, São Paulo, Parábola.

Esqueda, M. (1997): RÓNAI PÁL: Conflitos entre a profissionalização do tradutor e a teoria e a prática da tradução, Campinas,UNICAMP. 
Esqueda, M. (2004): O TRADUTOR PAULO RÓNAI: o desejo da tradução e do traduzir, Ph.D Dissertation, Campinas, UNICAMP.

Hirsch, I. (2002): Histórias dos EUA made in Brazil, Ph.D Dissertation, University of São Paulo. Martins, Marcia (ed.) (1999): Tradução e Multidisciplinaridade, São Paulo,Humanitas/USP.

Martins, Marcia (ed.) (2004): Visões e identidades brasileiras de Shakespeare, Rio de Janeiro, Lucerna.

Meyer, M. (1996): Folhetim, São Paulo, Cia. das Letras.

Milton, J. (1993): O poder da tradução, São Paulo, Ars Poetica.

Mitton, J. (ed.) (2001): Emerging Views on Translation History in Brazil, CROPn. 6, São Paulo, Humanitas FFLCH/USP.

Milton, J. (2002): The book club and translation, São Paulo, EDUSC.

PAes, J. P. (1990): Tradução: a ponte necessária, São Paulo, Ática.

Pagano, A. (ed.) (2001): Estudos da tradução no Brasil/Translation Studies in Brazil, Belo Horizonte, BB Martins.

SAntiago, V. (2004): “To be or not to be natural: clichés of emotion in screen translation," META $49-1$.

Santiago, V. (2004): Topics in audiovisual translation, Amsterdam, John Benjamins.

Torres, M. H. (2001): Variations sur l'étranger dans le lettres brésiliennes, Thèse de doctorat, Katholoeke Universiteit Leuven, KUL, Belgique.

Vieira, E. (1992): Por uma teoria pós-moderna de tradução, PhD Dissertation UFMG, Belo Horizonte.

Wyler, L. (2003): Línguas, poetas e bacharéis: uma crônica da tradução no Brasil, Rio de Janeiro, Rocco. 